\title{
Resistance of the Collateral Ligaments of the Femorotibial Joint in Domestic Dogs (Canis lupus familiaris LINNAEUS, 1758)
}

\author{
M. D. Faria ${ }^{1} \quad$ L. O. Regis² \\ A. Gradela ${ }^{1}$ \\ A. C. Constantino ${ }^{3}$ \\ N. C. Olivier ${ }^{4}$ \\ J. Pereira Neto ${ }^{5}$
}

${ }^{1}$ Laboratório de Anatomia dos Animais Domésticos e Silvestres, Curso de Medicina Veterinária, Universidade Federal do Vale do São Francisco - Univasf, Petrolina, Brazil

${ }^{2}$ Médica Veterinária Autônoma, Petrolina, Brazil

3 Programa de Pós-graduação em Ciências da Saúde e Biológicas, Universidade Federal do Vale do São Francisco - Univasf, Petrolina, Brazil

${ }^{4}$ Laboratório de Ensaio dos Materiais, Curso de Engenharia Mecânica, Universidade Federal do Vale do São Francisco - Univasf, Juazeiro, Brazil

${ }^{5}$ Departamento de Tecnologia e Ciências Sociais, Curso de

Agronomia, Universidade do Estado da Bahia - UNEB, Juazeiro, Brazil

\begin{abstract}
Address for correspondence M. D. Faria, Laboratório de Anatomia dos Animais Domésticos e Silvestres, Curso de Medicina Veterinária, Universidade Federal do Vale do São Francisco - Univasf, Rodovia BR 407, Km 12, s/n, Lote 543, Projeto de Irrigação Senador Nilo Coelho C1, CEP 56300-990, Petrolina, PE, Brazil (e-mail: marcelo.faria@univasf.edu.br).
\end{abstract}

J Morphol Sci 2018;35:64-69.

\begin{abstract}
Keywords

- arthrology

- material resistance

- knee

Introduction This work aimed to demonstrate the resistance of the femoral-tibial joint collaterals of 60 dogs of undefned breed, euthanized at the Zoonoses Control Centre of the city of Petrolina (PE), North-Eastern Brazil.

Materials and Methods The femur-tibial articulation was dissected to expose the collateral ligaments. Bones were cut on the distal third of the femur and the proximal third of tibia and fibula. The knee joint was kept bound only by the collateral ligaments and then submitted to destructive mechanical tests, evaluating the deformation of the ligaments (mm) per unit of time, (seconds), and the joint resistance.

Results We could observe no side effects of contralateral joints. In a destructive mechanical assay, we detected that the medial collateral ligaments ruptured earlier than the lateral ones. The resistance of the lateral and medial ligament of the right limb of females was respectively $537.1 \mathrm{~N} \pm 413.6$ and $360.1 \mathrm{~N} \pm 228.6$; while in males, were of $632.4 \mathrm{~N} \pm 333.4$ e $440.4 \mathrm{~N} \pm 227.1$. About the left antimere, the females presented $442.4 \mathrm{~N} \pm 288$ resistance on the lateral ligament and $417.4 \mathrm{~N} \pm 190.6$. In males, the resistance was $605.8 \mathrm{~N} \pm 316.1$ e $548.6 \mathrm{~N} \pm 2,333.7$, respectively.

Conclusion The results of our research will allow the development of synthetic tissues to replace the natural ligament of dogs in cases of rupture or degeneration.
\end{abstract}

\section{Introduction}

There is a low agreement on the origin of dogs. Paleontological studies suggest that canids have been existing for over 30 million years, together with the other mammalians and primates. Researchers, through archaeological records and genetic sequencing of wolves and dogs, try to discover the real origin of dogs.

received

July 23, 2017

accepted

February 8, 2018

$10.1055 / \mathrm{s}-0038-1660495$ ISSN 2177-0298.
Archaeological records of the fossilized specimen, allowed to estimate how long ago the first canine teeth appeared. However, until now it has not been possible to recognize the differentiation between dogs and wolves, due to the similarity between the two species. DNA allows the determination of the location and species that have domesticated them.

During prolonged periods of drought or famine, some wild animals, in search of food, approached humans. These events

Copyright @ 2018 by Thieme Revinter

Publicações Ltda, Rio de Janeiro, Brazil

License terms 
marked the beginning of domestication of dogs. ${ }^{1}$ The man began to interfere in the evolution of canids using artificial selection between different species (consider the option of between/among, and species, subspecies or varieties, as considering the complex taxonomy of canids) of wolves. From these experiences originated the different breeds of domestic dogs that are existing today. A well-accepted theory states that the domestic dog descends from the gray wolf (Canis lupus lupus), which has been wiped out by civilization. Modern studies have shown that dogs retain much of the wolf's wild instincts: territorialism, hunting, and attitude for shepherding.

The daily habits in the cities contribute to the solitude of human beings, increasing the presence of domestic animals, such as dogs and cats in homes, which become families members. The enhancement of concern about pets welfare influences the frequency of visits to the veterinarian.

Articulation is the contact between bone surfaces, allowing sliding between them, bone growth and movement in response to muscle contraction. The femorotibial joint ${ }^{2}$ is a synovial joint (diarthrosis), that is, it has the synovial fluid, which has the functions of lubrication, nutrition, shock absorption, increased congruence between the bone parts, besides allowing the locomotion. The articular capsule, composed of the synovial and fibrous membrane, envelops the femorotibial joint. The former is responsible for producing the synovial fluid, the latter, for maintaining the stability of the joint and movement. According to its movements, it is classified as hinge and uniaxial, allowing almost exclusively flexion and extension.

The femorotibial joint includes the condyles of the femur, the structures of the proximal epiphysis of the tibia and the interposed articular meniscus or semilunar cartilage. The surface of the condyles of the tibia does not conform to the femoral condyles and are in contact with only a small part of them. ${ }^{3}$ According to König and Liebich (2002), ${ }^{4}$ the femorotibial joint has two ligaments on both sides, which are extra-articular ligaments, called lateral collateral and medial collateral ligaments, that lie between the epicondyles of the femur and the tibia. The lateral collateral ligament inserts, without union with the lateral meniscus, in the lateral condyle of the tibia and the head of the fibula. The medial collateral ligament maintains contact with the medial meniscus and enters the medial condyle of the tibia. The primary function of these ligaments is to prevent lateral and medial movement of the knee.

According to Dyce et al., ${ }^{5}$ palpation of the femorotibial joint reveals the following features of the skeleton: the patella with its patellar ligament; the trochlear ridges and the outer surfaces of the femoral condyles; the sesamoid bones (at the origin of the gastrocnemius muscle); the head of the fibula; the margin of the lateral condyle adjacent to the fibula; the tuberosity; the extensor sulcus; the medial surface of the tibia and the medial and lateral collateral ligaments. The sharpest internal feature of the joint is free communication between various synovial compartments.

The femorotibial joint is very complex, and the largest in the body, consolidated by muscles and ligaments deficiently, which consequently suffer severe trauma. ${ }^{6}$ It is a condylar joint, composed of medial and lateral femoral condyles, mak- ing contact through the meniscus interposed to the proximal articular face of the tibia. It consists of the distal end of the femur, the proximal end of the tibia and the patella. This articulation is cable of performing flexions, extensions, and slight rotations. The femorotibial joint is the main joint to bear the weight of the body. The collateral ligaments attach to the joint capsule, allowing support to this structure, being, however, totally extra-articular and responsible for the varus and valgus movements of the tibia. ${ }^{7}$ According to Leopizzi, ${ }^{8}$ a dog's knee is a bi-articulated "transmission joint," stabilized by secondary restraints that are required from the biomechanical demand and the ligament system. The movement of the knee is determined by ligaments and not by its bone structure. According to Slocum and Slocum, ${ }^{9}$ it is a joint with two degrees of freedom. The former allows flexion and extension movements on the transverse axis at the level of the femoral condyles, the latter, the rotation around the long axis of the tibia. Dejardin et al ${ }^{10}$ reported that the femorotibial joint is a diarthrodial joint of the gingivitis and uniaxial type, mainly consisting of flexion and extension movements. The joint is composed of a cavity, articular capsule, articular cartilage, synovial fluid, Subchondral bone, articular ligaments and two meniscus - one medial and one lateral. ${ }^{11}$ According to Oda, ${ }^{12}$ the lateral ligaments (lateral and medial) are responsible for the sustentation of the femorotibial joint. They demarcate movements of the vagus type, where the head of the femur establishes with its body an angle greater than $135^{\circ}$ (medial collateral ligament) and virus presenting angulation less than $120^{\circ}$ (lateral collateral ligament).

According to Vasseur (apud Oda, 2008), ${ }^{12}$ the juncture among the femur, tibia, and patella is formed by two functionally differentiated joints. The femorotibial joint gives weight support and the femoropatellar joint, increases mechanical efficiency of the quadriceps muscle, facilitates the movement of extension and keeps the patella in the trochlear groove.

Biometry (from the Greek bios = life, metron = measurement) is the study of the physical characteristics of an individual or a population, taking into account their dimensions, mass, and volume or simply their conformation and visual, physical aspects. ${ }^{13}$ There are two methods for determining biometrics: somatoscopy, also known as zooscopy, and somatometry or zoommetry. The first, however descriptive analyze the characteristics, such as coat color, eye color, skull conformation. Is not very reliable, since even within the same species, there are several breeds. The somatometry is considered more reliable because it bases on measurements of dimensions, mass, and volume.

Given the importance of the ligaments in the stabilization of the joints and the several pathologies that affect them, the present study aimed to determine the resistance and deformation of the collateral ligaments of the femorotibial joint in dogs, correlating them with body biometric parameters and sex.

\section{Materials and Methods}

This study was approved by the Ethical Committee on Human and Animal studies of the Federal University of the São Francisco Valley under protocol number 22041021. 


\section{Collection of Material}

Sixty previously euthanized medium sized dogs of undefined breeds, both males and females, were collected from the Zoonoses Control Center (CCZ) of the city of Petrolina (Pernambuco State, Brazil). After the collection, the animals were transported to the laboratory of the anatomy of domestic and wild animals (Laboratório de Anatomia dos Animais Domésticos e Silvestres) of the Univasf, located in the agrarian sciences Campus.

\section{Body Biometry}

To measure the body Biometry, we used a metric tape and a millimetric caliper, with the aim of obtaining:

- Height: determined by measuring the distal extremities of the thoracic limbs to the shoulder region, between the spinal processes of the thoracic vertebrae, located between the scapulae, referred to as the withers;

- Length: conferred through the interval along the spine, between the nuchal crest and the tail insertion;

- Scapular girdle (width): determined through the measurement between contralateral scapular spines;

- Pelvic girdle (width): determined by measuring the coxal tuberosities of the iliac wings;

- Height of the thorax: checked by taking the measurements between the base of the sternum and the spinous processes of the seventh or eighth thoracic vertebrae;

- Height of the abdomen: checked by measuring between the umbilical scar and the spinous processes of the third or fourth lumbar vertebrae;

- Cranial chest length: determined by the interval between the frontonasal suture and the nuchal ridge;

- Nasal length: obtained through the range between the apex of the nose and the frontonasal suture;

- Head width: checked by measuring the space between the lateral sides of the contralateral zygomatic arches;

- Head height: determined through the interval between the nuchal crest and the angle of the mandible.

Body mass was determined by a digital analytical balance (Techline®, São Paulo - SP, Brazil) which expresses the value in kilograms.

\section{Dissection of Material}

In the Laboratory of Anatomy of Domestic and Wild Animals of Univasf, the material was processed, and the dissections were made for the femoral-tibial joint to be revealed with its respective collateral ligaments ( $\mathbf{- F i g . 1}$ ). All the muscles surrounding the knee joint were separated and cut.

Other supporting structures, such as capsule, lateral and medial menisci, cranial patellar ligaments, medial patellar caudal patellar ligaments, lateral femoropatellar ligament, meniscofemoral ligament, caudal tibial ligament of the lateral meniscus, cranial cruciate ligament, caudal crossover, interosseous ligament, vessels and nerves, were cut using surgical material (anatomical tweezers, surgical scissors).

Then, with the aid of a band saw, the distal third of the femur was fractured, as well as the proximal third of the tibia and fibula, suspended only through the collateral ligaments.

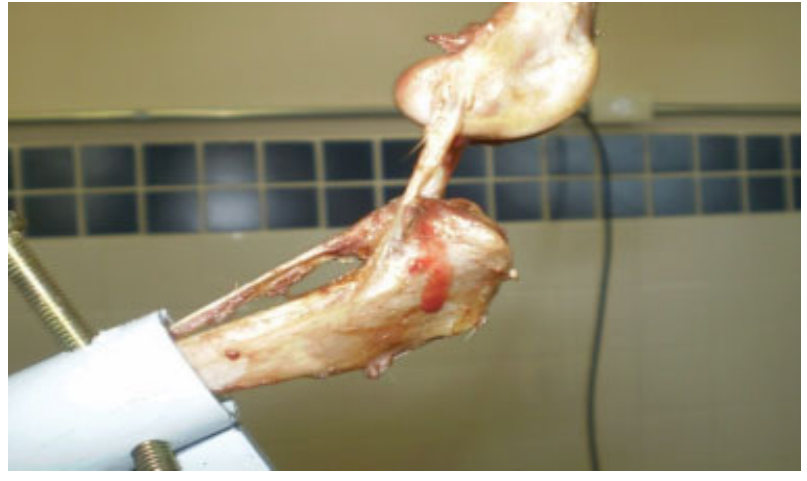

Fig. 1 Photograph showing the collateral ligaments of the left femorotibial joint (arrows) - Petrolina, 2016.

\section{Biometry of Collateral Ligaments}

After dissection, the dimensions of the collateral ligaments of the femorotibial joint, such as the thickness (medial-lateral) and the width (craniocaudal) of both antimeres, were determined.

\section{Destructive Mechanical Testing}

After dissection, the joint parts were transported to the Laboratory for the study of the Materials (Laboratório de Ensaios de Materiais) of the mechanical engineering course, in the Campus of the city of Juazeiro of the same University, located in Município de Juazeiro, Bahia State (Latitude - $09^{\circ} 24^{\prime} 42$," Longitude $40^{\circ} 29^{\prime} 55$." Altitude $368 \mathrm{~m}$ ), A mechanical device was developed with claws that allowed the bone structures to fit together with their respective collateral ligaments.

The apparatus used for the experiment was the Universal Machine for electromechanical and micro processed tests Digital Line (EMIC $®$ - DL10000, São José dos Pinhais-PR, Brazil). The superior claw anchored to the distal epiphysis of the femur. The inferior, the proximal epiphysis of the tibia (-Figs. 2 and $\mathbf{3}$ ). Force $(\mathrm{N})$ was then applied, analyzing the displacement in millimeters $(\mathrm{mm})$ of the upper jaw, evaluating the deformation of the ligaments $(\mathrm{mm})$ per unit of time (s). It is important to emphasize that the angulation of this joint is of fundamental importance in the destructive mechanical test, mimicking the orthostatic position of the part in the living animal.

After the fixation of the bone pieces in the fixation devices, the traction was promoted to evaluate the proposed hypotheses (-Fig. 1).

\section{Statistical Analysis}

For statistical analysis, the SAS 9.2 help program and the Satterthwaite test were used, with significance $(r)$ less than 0.05 , as well as to obtain the correlations used a significance higher than 0.7 (SAS, 2010). ${ }^{14}$ Thus, the data were tabulated and linear scatter plots were prepared, to establish existing correlations.

\section{Results and Discussion}

-Tables 1 and 2 describe the results of the experiments, making numerical details (mean and standard deviation) of 


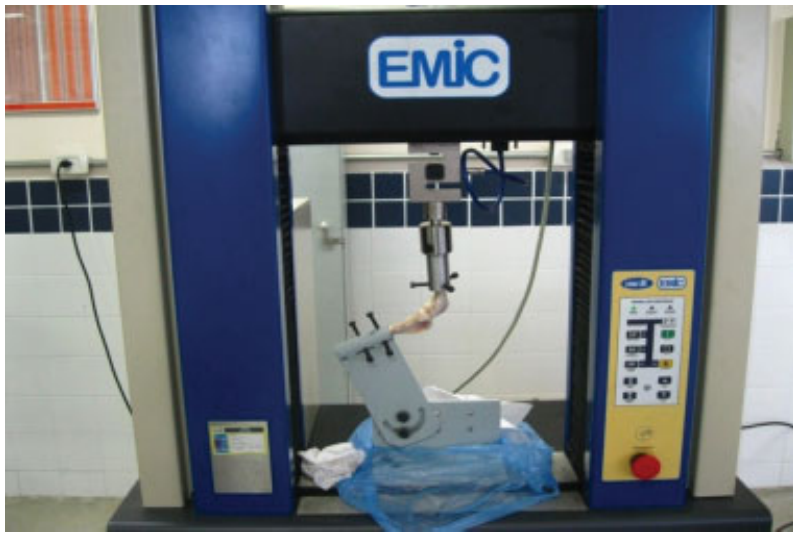

Fig. 2 Photograph showing the articulation (arrow) fixed to the Universal Machine of Electromechanical and Micro processed Tests (Digital Line, EMIC) - Petrolina, 2016.

both body biometric data and data on the collateral ligaments of the femorotibial joint, respectively. It is important to highlight that the statistical treatment was very detailed, to establish correlations between the body biometry and the biometry of the collateral ligaments of the femorotibial joint, as well as to elucidate differences inherent to the contralateral ligaments. The graph above displays the correlations between the collateral ligaments of the femorotibial joint. Data were obtained from the SAS 9.2 help program and the Satterthwaite test, considering a significance level ( $\mathrm{r}$ ) greater than 0.7:

- The medial-lateral thickness of the left medial collateral ligament showed a significant correlation with the medial-lateral thickness of the lateral ligament of the same antimere;

- The resistance of the right medial collateral ligament obtained a correlation with the resistance force related to the lateral ligament of the same antimere;

Table 1 Biometric data of dogs collected by the CCZ of Petrolina (PE) - Petrolina, 2016

\begin{tabular}{|l|l|l|l|l|}
\hline \multirow{2}{*}{ Body parameters } & \multicolumn{2}{l|}{ Average } & \multicolumn{2}{l|}{ Standard-Deviation } \\
\cline { 2 - 5 } & Females & Males & Females & Males \\
\hline Body mass $(\mathrm{kg})$ & 9.9148 & 11.8424 & 3.7415 & 3.9748 \\
\hline Height $(\mathrm{cm})$ & 51.9444 & 55.5758 & 8.0912 & 6.3837 \\
\hline Length $(\mathrm{cm})$ & 61.0741 & 65.4394 & 7.3376 & 7.1783 \\
\hline Shoulder girdle $(\mathrm{cm})$ & 47.0741 & 52.3333 & 6.6906 & 10.8359 \\
\hline Pelvic girdle $(\mathrm{cm})$ & 38.7778 & 44.6970 & 8.1256 & 13.5381 \\
\hline Chest height $(\mathrm{cm})$ & 27.2593 & 29.0909 & 4.6624 & 4.6122 \\
\hline $\begin{array}{l}\text { Abdomen } \\
\text { height }(\mathrm{cm})\end{array}$ & 24.9630 & 28.2424 & 4.8949 & 8.5221 \\
\hline Nasal length $(\mathrm{cm})$ & 7.1519 & 7.5879 & 1.5235 & 1.0942 \\
\hline $\begin{array}{l}\text { Cranial carton } \\
\text { length }(\mathrm{cm})\end{array}$ & 9.9296 & 10.7364 & 2.0615 & 2.0106 \\
\hline Head width $(\mathrm{cm})$ & 8.4963 & 9.1758 & 1.9806 & 1.6961 \\
\hline Head height $(\mathrm{cm})$ & 7.8556 & 7.8909 & 2.2268 & 2.2413 \\
\hline
\end{tabular}

Abreviations: cm, centimeter; kg, kilogram.

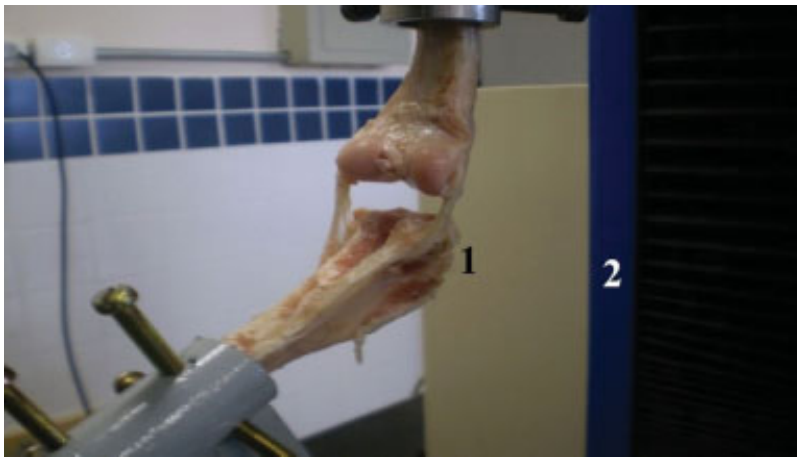

Fig. 3 Photograph showing the medial (1) and lateral (2) collateral ligaments of the femorotibial joint of a not - defined dog submitted to a destructive mechanical test - Petrolina, 2016.

- The strength of the lateral collateral ligament of the right antimere showed a correlation with the force of the medial collateral ligament of the same antimere and the displacement of the right lateral collateral ligament;

- The displacement of the left lateral collateral ligament was correlated with its resistance force.

Table 2 Biometry of the lateral and medial collateral ligaments of the femorotibial joint of medium-sized dogs from the Centro de Controle de Zoonoses de Petrolina (PE). Width (W) and thickness $(T)$ are expressed in centimeters. The strength of resistance (FR) is expressed in Newtons. The displacement of the claws of the destructive mechanical test (D) is expressed in millimeters - Petrolina, 2016

\begin{tabular}{|c|c|c|c|c|c|}
\hline \multirow[t]{2}{*}{$\begin{array}{l}\text { Collateral } \\
\text { Ligaments }\end{array}$} & \multirow[t]{2}{*}{ Aspect } & \multicolumn{2}{|l|}{ Average } & \multicolumn{2}{|c|}{$\begin{array}{l}\text { Standard } \\
\text { Deviation }\end{array}$} \\
\hline & & Females & Males & Females & Males \\
\hline \multirow{4}{*}{$\begin{array}{l}\text { Right } \\
\text { medial } \\
\text { collateral } \\
\text { ligament }\end{array}$} & $\mathrm{L}$ & 2.4741 & 2.8970 & 0.7694 & 1.0792 \\
\hline & $\mathrm{E}$ & 0.8915 & 0.9273 & 0.5431 & 0.6187 \\
\hline & FR & 360.1 & 440.4 & 228.6 & 227.1 \\
\hline & D & 16.1111 & 17.3333 & 7.0674 & 8.6663 \\
\hline \multirow{4}{*}{$\begin{array}{l}\text { Left } \\
\text { medial } \\
\text { collateral } \\
\text { ligament }\end{array}$} & $\mathrm{L}$ & 2.5852 & 2.9576 & 0.8570 & 1.0220 \\
\hline & $E$ & 0.7600 & 0.6776 & 0.7915 & 0.6484 \\
\hline & FR & 417.4 & 548.6 & 190.6 & 233.7 \\
\hline & $\mathrm{D}$ & 17.4815 & 19.0303 & 6.8127 & 8.0409 \\
\hline \multirow{4}{*}{$\begin{array}{l}\text { Right } \\
\text { lateral } \\
\text { collateral } \\
\text { ligament }\end{array}$} & $\mathrm{L}$ & 2.3815 & 2.4788 & 0.5994 & 0.6800 \\
\hline & $\mathrm{E}$ & 0.6996 & 0.5927 & 0.5905 & 0.4832 \\
\hline & FR & 537.1 & 632.4 & 413.6 & 333.4 \\
\hline & $\mathrm{D}$ & 25.9259 & 38.4545 & 15.3771 & 59.8410 \\
\hline \multirow{4}{*}{$\begin{array}{l}\text { Left } \\
\text { lateral } \\
\text { collateral } \\
\text { ligament }\end{array}$} & $\mathrm{L}$ & 2.4630 & 2.1879 & 0.8954 & 0.7253 \\
\hline & $\bar{E}$ & 0.7041 & 0.6233 & 0.6661 & 0.6074 \\
\hline & FR & 442.4 & 605.8 & 288.0 & 316.1 \\
\hline & $\mathrm{D}$ & 20.0741 & 24.3939 & 11.4352 & 12.8207 \\
\hline
\end{tabular}



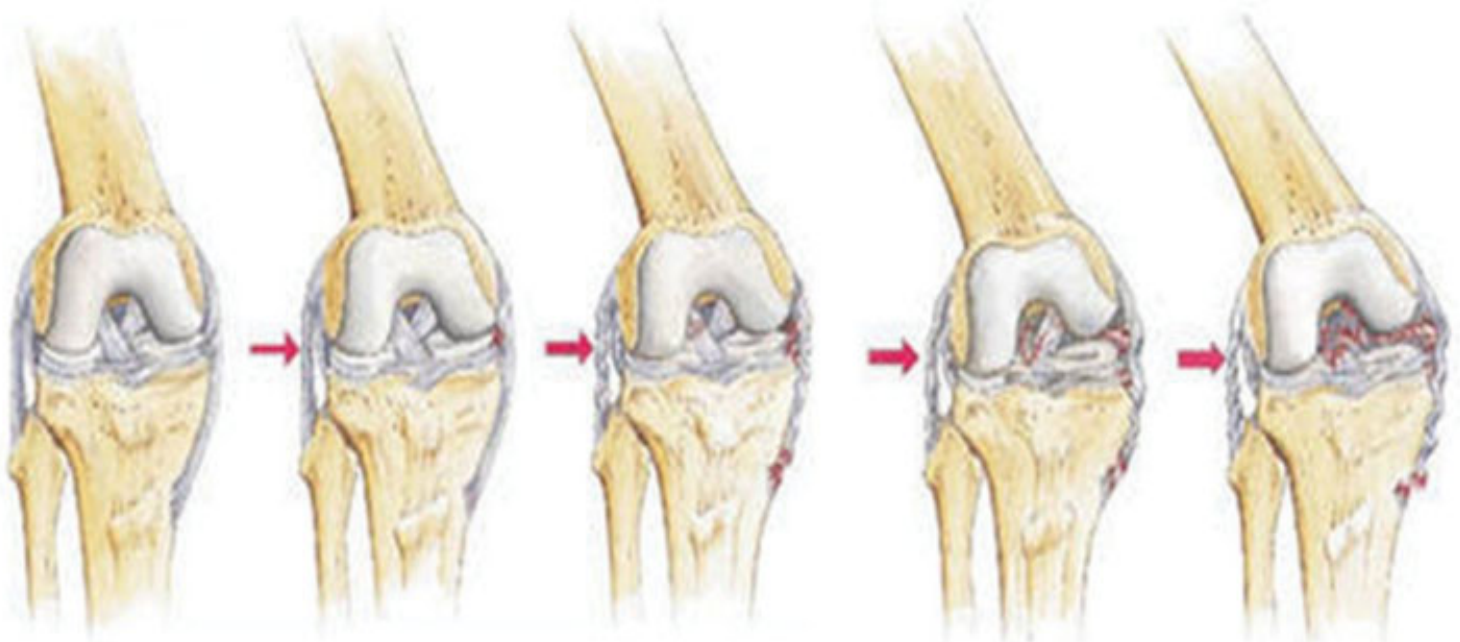

Martin Dunitz 2001

Fig. 4 Diagram demonstrating how rupture of the medial collateral ligaments occurs (Reider, 1996). ${ }^{17}$

The data treated through statistical studies showed that there was no significant difference between the collateral ligaments of the femorotibial joint, as considering the correlation between the thicknesses and the displacements of the claws, without significant difference, that is, they have the same length and thickness. However, during the destructive mechanical tests, the medial collateral ligaments ruptured anteriorly to the lateral ones, evidencing more resistance of the latter.

In $10 \%$ of cases, before the rupture of the collateral ligaments, fibular fractures occurred, pointing out that, in certain animals, the ligament is as resistant as the bone itself.

In $19.2 \%$ of the animals, we could observe disarticulation between the tibia and fibula, with rupture of the interosseous ligament before the rupture of the collateral ligaments.

The statistical analysis highlighted that the resistance and the dimensions of the ligaments have no correlation with the mass and the body dimensions of the animals, that is, they do not depend on the size of the dogs.

Rodrigues, ${ }^{15}$ reported that traumatic injuries represent $80 \%$ of the pathologies of the human knee because the osteoligament system is very complex and often subjected to trauma. We could verify the complexity of the articulation through the number of tissue excisions, promoted during dissections of the collateral ligaments when ligaments, muscles and other adjacent tissues were rebounded.

In the limited existing literature concerning the collateral ligaments of the femorotibial joint, it was possible to verify that the rupture of the medial is more constant, but does not manifest, characteristically, a significant joint effusion, because the collateral ligaments are positioned as extraarticular structures in humans. ${ }^{16}$ According to Reider, ${ }^{17}$ the medial collateral ligament of the human knee humans is more frequently injured due to the combined forces or a valgus, external rotation and valgus force. The rupture of the medial collateral ligament occurs as a result of a blow on the lateral side of the knee, with the leg fixed (-Fig. 4).
The magnitude of the valgus lesion causes a rupture, first, of the medial collateral ligament and, probably afterward, of the cranial cruciate ligament ( $\mathbf{- F i g . 5}$ ).

In the present study, using the femorotibial joints of dogs, we could observe that the collateral ligaments were extracapsular and that in $34.5 \%$ of the right antimere and $29.2 \%$ of the left, there was also the same relation, that is, the medial collateral ligament fractured more easily than the lateral one (-Fig. 6). The fracture occurs because of the support of the mass of the dog, which fosters a higher deposition of fibroblasts to support the acting forces. ${ }^{4}$ In the other animals, there was no significant difference between the resistances. We could not comment on the cranial cruciate ligament since we did not study it and we removed it before our tests.

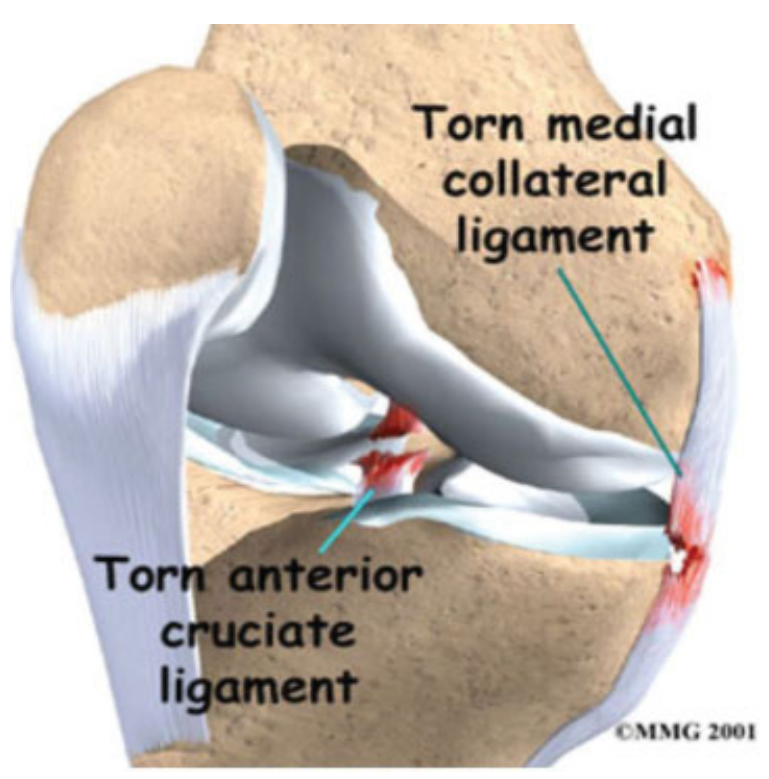

Fig. 5 Diagram showing the medial collateral ligament and ruptured cranial cruciate ligament (Reider, 1996). ${ }^{17}$ 


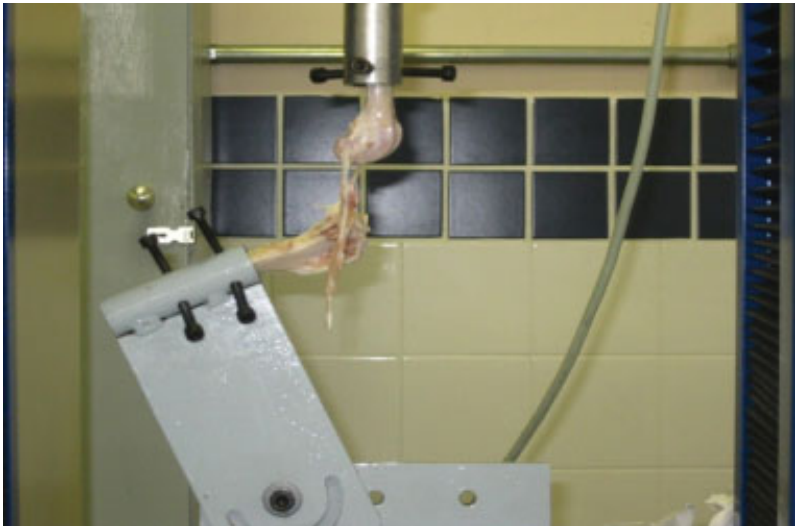

Fig. 6 Torn medial collateral ligament (arrow) - Petrolina, 2016.

The size of most of the ligaments of the body is associated with the body size. We could not see such relation between the development of the collateral ligaments of the femorotibial joint and the mass or the size of the body.

\section{Conclusion}

Given the obtained results, we could observe no correlations between the somatometric data and the resistance of the femorotibial collateral ligaments, that is, they do not depend on the size of the animals. The destructive mechanical essay pointed out that the medial collateral ligaments are more easily prone to ruptures than the lateral ones. This research will help the development of synthetic tissues to substitute the natural ligament in cases of rupture or degenerative injury since their resistance has already been assessed in dogs.

\section{Acknowledgments}

The authors would like to thank the Center for the zoonoses control of the city of Petrolina (PE) for the supply of corpses and the National Council for Cientific and Technologic development (Conselho Nacional de Desenvolvimento Científico e Tecnológico - CNPq) for the scientific initiation grant.

\section{References}

1 Faria MD. Dimensões e massa dos órgãos internos de cães Pastores Alemães (Canis familiaris LINNAEUS, 1758) [thesis]. São Paulo: Faculdade de Medicina Veterinária e Zootecnia, Universidade de São Paulo, 2007:245-Tese de Doutorado em Anatomia dos Animais Domésticos e Silvestres

2 Wava. Nomina Anatomica Veterinaria. $5^{\text {th }}$ ed. Hannover: WAVA; 2005:117-180

3 Getty R. Sisson/Grossman: anatomia dos animais domésticos. $5^{\text {th }}$ ed. Rio de Janeiro: Guanabara Koogan; 1986:1413-1415

4 König HE, Liebich HG. Anatomia dos animais domésticos: texto e atlas. Porto Alegre. Art Med 2002;1:203-221

5 Dyce KM, Sack WO, Wensing CJG. Tratado de anatomia veterinária. 3. ed. Rio de Janeiro: Elsevier; 2004:459-460

6 Gould J III. A fisioterapia na ortopedia e na medicina do esporte. $2^{\mathrm{a} e d .}$ São Paulo: Manole; 1993

7 Vasseur PB. Articulação do joelho. In: Slatter D. Manual de cirurgia de pequenos animais, $2^{a}$ ed. São Paulo: Manole; 1998;2:2149-2180

8 Leopizzi N. Estudo experimental das propriedades mecânicas do ligamento cruzado de cães em diferentes graus de flexão do joelho [dissertation]. São Paulo: Faculdade de Medicina Veterinária e Zootecnia, Universidade de São Paulo, 1998:152 - Dissertação de Mestrado em Fisiopatologia Experimental

9 Slocum B, Slocum D. Algorithm for diagnosis and treatment of the stifle for cranial cruciate ligament rupture: diagnostic tests. In: Bojrab MJ. Current techniques in small animal surgery, $4^{a}$ ed. Baltimore: Williams \& Wilkins; 1998:1187-1193

10 Dejardin LM, Nemzek JA, Arnoczky SP. Stifle injuries. In: Bloomberg MS, Dee JF, Taylor RA. eds. Canine sports medicine and surgery. Philadelphia: Saunders; 1998:138-150

11 Piermattei DL, Flo GL. Manual de ortopedia e tratamento das fraturas dos pequenos animais. 3ed. São Paulo: Manole; 1999:161-189

12 Oda SGS. Descrição do estudo biomecânico de duas técnicas extracapsulares para estabilização do joelho com ruptura do ligamento cruzado cranial em cães. São Paulo: Faculdade de Medicina Veterinária e Zootecnia, Universidade de São Paulo; 2008:115 - Dissertação de Mestrado em Clínica Cirúrgica Veterinária

13 Wang J, Hihara E. A unified formula for calculating body surface area of humans and animals. Eur J Appl Physiol 2004;92(1-2):13-17

14 SAS Institute. SAS help and documentation 9.2. Cary. CD-ROM; 2006

15 Rodrigues AD. Protocolo acelerado de intervenção fisioterapêutica no pós-operatório de lesão meniscal [thesis]. Cascavel: Faculdade Assis Gurgacz, 2006:79 Trabalho de Conclusão do Curso em Fisioterapia

16 Grava JPS, Peres AE, Camanho GL, Lasmar NP. Patologia do quadril na atividade esportiva. In: Lasmar NP, Camanho GL, Lasmar RCP. Medicina do esporte. Rio de Janeiro: Revinter; 2000:505

17 Reider B. Medial collateral ligament injuries in athletes. Sports Med 1996;21(02):147-156 